\title{
Retraction Note to: The characteristics of rainfall in coastal areas and the intelligent library book push system oriented to the Internet of Things
}

\author{
Hailing $\mathrm{Chi}^{1}$
}

Published online: 3 November 2021

(c) Saudi Society for Geosciences 2021

Retraction Note to: Arabian Journal of Geosciences (2021) 14: 1069 https://doi.org/10.1007/s12517-021-07408-5

The Editor-in-Chief and the Publisher have retracted this article because the content of this article is nonsensical. The peer review process was not carried out in accordance with the Publisher's peer review policy. The author has not responded to correspondence regarding this retraction.

The original article can be found online at https://doi.org/10.1007/ s12517-021-07408-5.

Hailing Chi

chlsci123456@126.com

1 Library, Zibo Vocational Institute, Zibo 255314, Shandong, China 